\title{
Serum Triiodothyronine and Thyroxine in the Neonate and the Acute Increases in These Hormones Following Delivery
}

\author{
J. Abuid, D. A. Stinson, and P. R. Larsen \\ From the Division of Endocrinology and Metabolism, Department of Medicine \\ and the Department of Pediatrics, University of Pittsburgh School of Medicine, \\ Pittsburgh, Pennsylvania 15213
}

\begin{abstract}
A B S T R A C T Low triiodothyronine $\left(\mathrm{T}_{3}\right)$ and high normal thyroxine $\left(T_{4}\right)$ concentrations are present in cord sera from full term infants. To examine this phenomenon further, radioimmunoassay of $T_{3}$ and $T_{4}$ was carried out in paired maternal and cord sera as well as capillary sera from neonates at different intervals after delivery. Free $T_{3}$ and free $T_{4}$ concentrations were also estimated in cord and maternal sera by equilibrium dialysis. In 12 paired specimens, the $\mathrm{T}_{3}$ concentration in cord sera was significantly lower than the maternal level ( $51 \pm 4$ vs. $161 \pm 11 \mathrm{ng} / 100 \mathrm{ml}$, mean $\pm \mathrm{SE}$ ). Mean free $T_{3}$ concentration was also lower in the cord samples $(0.15 \pm 0.02$ vs. $0.31 \pm 0.04 \mathrm{ng} / 100 \mathrm{ml})$, whereas total and free $T_{4}$ concentrations were not significantly different. Umbilical vein and artery samples from 11 neonates did not differ significantly in their $T_{3}$ and $T_{4}$ concentrations. In seven infants the mean $T_{3}$ concentration increased from $51 \pm 3 \mathrm{ng} / 100 \mathrm{ml}$ at delivery to $79 \pm 13$ at $15 \mathrm{~min}$ and $191 \pm 16$ at $90 \mathrm{~min}$. In four other infants the mean $T_{3}$ concentration at 24 and $48 \mathrm{~h}$ was not significantly different from the $90 \mathrm{~min}$ value of the previous group. Less pronounced changes were observed for $T_{4}$ which increased from $12.3 \pm 2.0 \mu \mathrm{g} / 100$ $\mathrm{ml}$ (mean $\pm \mathrm{SE}$ ) at delivery to $14.1 \pm 1.9$ at $90 \mathrm{~min}$ and appeared to have reached a plateau at approximately twice the cord value by $24-48 \mathrm{~h}$ after delivery.

The maternal-fetal gradient observed for free $T_{3}$ is further evidence of the autonomy of the fetal thyroidpituitary axis. The time course of the abrupt increase in serum $T_{3}$ in the neonate suggests that it results from the earlier acute increase in serum $\mathrm{TSH}$ which occurs shortly after birth. This suggests that the neonatal thy-
\end{abstract}

This material was presented in part at the American Thyroid Association Meeting, September 1972.

Dr. Larsen is a Career Development Awardee, U. S. Public Health Service Award no. AM-70401.

Received for publication 1 Novemler 1972 and in revised form 26 necember 1972. roid contains significant quantities of $\mathrm{T}_{3}$. Therefore, unavailability of thyroidal $T_{3}$ does not appear to explain the low total and free $T_{3}$ concentrations present in the sera of newborns.

\section{INTRODUCTION}

We have recently reported that the concentration of triiodothyronine $\left(\mathrm{T}_{3}\right)^{1}$ in cord sera from full term infants is in the range observed in hypothyroid adults while thyroxine $\left(T_{4}\right)$ levels are in the high normal adult range (1). The reason for this discrepancy is not immediately apparent. In order to examine this phenomenon more closely and to determine whether free $T_{3}$ concentration was also decreased, paired maternal and cord sera as well as capillary samples from neonates were examined. In addition, the relative changes in $T_{3}$ and $\mathrm{T}_{4}$ in the neonate were compared during the period of endogenous thyroid stimulating hormone (TSH) release which normally occurs at the time of delivery (2).

\section{METHODS}

Serum samples were obtained from patients at Magee Women's Hospital, Pittsburgh, Pa., after informed consent of the mother. All were normal pregnancies with either vaginal delivery or elective cesarian section. Maternal samples were taken immediately after delivery or just before hysterotomy. Cord samples were usually obtained by direct puncture of the umbilical vein or artery. Capillary blood from infants was obtained by heel puncture, $400 \mu \mathrm{l}$ of serum being adequate to measure total $T_{3}$ and $T_{4}$ levels.

$T_{s}$ immunoassay. Radioimmunoassay of $\mathrm{T}_{3}$ was performed as previously described using 50 and/or $25 \mu 1$ of serum (1). Incubation and antiserum dilution were adjusted to allow displacement of $10-20 \%$ of the tracer $\mathrm{T}_{3}$ by $12.5 \mathrm{pg}$

${ }^{1}$ Abbreqiations used in this paper: $\mathrm{DFT}_{3,}$, dialyzable fraction of $\mathrm{T}_{3} ; \mathrm{DFT}_{4}$, dialyzable fraction of $\mathrm{T}_{4} ; \mathrm{T}_{3}$, triiodothyronine; $\mathrm{T}_{4}$, thyroxine; TSH, thyroid stimulating hormone. 
TABLE 1

Total and Free Thyroid Hormone Concentrations in Paired Maternal and Cord Sera

\begin{tabular}{|c|c|c|c|c|c|c|c|c|c|c|c|c|}
\hline & \multicolumn{3}{|c|}{ Maternal } & \multicolumn{3}{|c|}{ Cord } & \multicolumn{3}{|c|}{ Maternal } & \multicolumn{3}{|c|}{ Cord } \\
\hline & $\mathrm{T}_{3}$ & $\mathrm{DFT}_{3}$ & $\mathrm{FT}_{3}$ & $\mathrm{~T}_{8}$ & $\mathrm{DFT}_{3}$ & $\mathrm{FT}_{3}$ & $T_{4}$ & $\mathrm{DFT}_{4}$ & $\mathrm{FT}_{4}$ & $T_{4}$ & $\mathrm{DFT}_{4}$ & $\mathrm{FT}_{4}$ \\
\hline & $\mathrm{ng} / 100 \mathrm{ml}$ & $\%$ & $n g / 100 \mathrm{ml}$ & $\mathrm{ng} / 100 \mathrm{ml}$ & $\%$ & $\mathrm{ng} / 100 \mathrm{ml}$ & $\mu \mathrm{g} / 100 \mathrm{ml}$ & $\%$ & $\mathrm{ng} / 100 \mathrm{ml}$ & $\mu \mathrm{g} / 100 \mathrm{ml}$ & $\%$ & $\mathrm{ng} / 100 \mathrm{ml}$ \\
\hline C. N. & 135 & 0.22 & 0.30 & 72 & 0.30 & 0.22 & 18.5 & 0.012 & 2.22 & 12.7 & 0.016 & 2.03 \\
\hline S. P. & 175 & 0.18 & 0.32 & 52 & 0.25 & 0.13 & 13.8 & 0.012 & 1.66 & 16.2 & 0.015 & 2.43 \\
\hline A. W. & 135 & 0.21 & 0.28 & 32 & 0.28 & 0.09 & 9.3 & 0.014 & 1.30 & 7.5 & 0.020 & 1.50 \\
\hline B. J. & 115 & 0.13 & 0.15 & 76 & 0.24 & 0.18 & 14.5 & 0.008 & 1.16 & 18.4 & 0.015 & 2.76 \\
\hline C. K.* & 198 & 0.16 & 0.32 & 42 & 0.39 & 0.16 & 15.6 & 0.008 & 1.09 & 8.2 & 0.016 & 1.31 \\
\hline C. L. & 108 & 0.23 & 0.25 & 39 & 0.27 & 0.10 & 8.4 & 0.013 & 1.09 & 9.0 & 0.017 & 1.49 \\
\hline J. B.* & 174 & 0.23 & 0.40 & 29 & 0.41 & 0.12 & - & - & - & - & - & - \\
\hline T. L.* & 123 & 0.40 & 0.49 & 46 & 0.35 & 0.16 & 9.6 & 0.013 & 1.25 & 11.7 & 0.012 & 1.40 \\
\hline Mean & 145 & 0.22 & 0.31 & 49 & 0.31 & 0.15 & 12.8 & 0.011 & 1.40 & 12.0 & 0.016 & 1.85 \\
\hline$\pm \mathrm{SEM}$ & 12 & 0.03 & 0.04 & 6 & 0.02 & 0.02 & 1.4 & 0.001 & 0.16 & 1.6 & 0.001 & 0.22 \\
\hline$P \ddagger$ & \multicolumn{6}{|c|}{$<0.025$} & \multicolumn{6}{|c|}{$<0.025$} \\
\hline$P \S$ & \multicolumn{6}{|c|}{$<0.005$} & \multicolumn{6}{|c|}{ NS } \\
\hline
\end{tabular}

* Delivered by elective cesarian section.

$\ddagger$ For the difference in dialyzable fraction ( $t$ test for paired samples).

$\S$ For the difference in free hormone concentration ( $t$ test for paired samples).

of unlabeled $T_{3}$. Results are the mean of at least two sets of duplicate determinations. All measurements (maternal and infant) of a given subject were performed simultaneously to eliminate interassay variability. $\mathrm{T}_{3}$ levels in normal adult sera are $110 \pm 25 \mathrm{ng} / 100 \mathrm{ml}$ (SD).

$T_{4}$ immunoassay. Radioimmunoassay of $\mathrm{T}_{4}$ was performed by a method similar to that used for $T_{3}$. This will be described in greater detail in a subsequent communication. ${ }^{2}$ The $T_{4}$ values obtained using this method correlate well with those obtained by the competitive binding protein technique (correlation coefficient, 0.97). The normal range for $T_{4}$ in euthyroid adults with normal thyroxine-binding globulin levels is $5.1-11.5 \mu \mathrm{g} / 100 \mathrm{ml}$.

Dialyzable fraction of $T_{3}$ and $T_{4}$. The dialyzable fraction of $\mathrm{T}_{3}$ and $\mathrm{T}_{4}\left(\mathrm{DFT}_{3}\right.$ and $\left.\mathrm{DFT}_{4}\right)$ was determined by a modification of the method of Oppenheimer, Squef, Surks, and

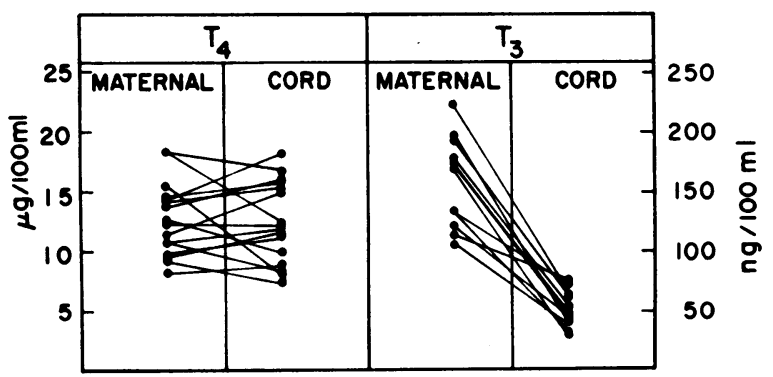

FIGURE 1 Total $T_{3}$ and $T_{4}$ concentrations in paired maternal and cord sera from full term infants. Samples were obtained from infants after either vaginal delivery (12 pairs for $T_{4} ; 8$ pairs for $T_{3}$ ) or elective cesarian section (4 pairs for both $T_{3}$ and $T_{4}$ ). Cord values correspond to umbilical artery, umbilical vein, or the mean of both determinations.

${ }^{3}$ Submitted for publication.
Haver (3). $\left[{ }^{131} \mathrm{I}\right] \mathrm{T}_{3}$ and predialyzed $\left[{ }^{125} \mathrm{I}\right] \mathrm{T}_{4}$ were used in order to obtain simultaneous determinations of both free fractions. Tracer enrichment was less than $2 \mu \mathrm{g} \mathrm{T}_{4} / 100 \mathrm{ml}$ and less than $1 \mu \mathrm{g} \mathrm{T}_{3} / 100 \mathrm{ml}$. Serum was diluted $1 / 25$ in Krebs-Ringer phosphate buffer $(\mathrm{pH} 7.4)$ containing 0.001 $\mathrm{M} \mathrm{Na}$ azide prior to dialysis. The dialyzable fraction is calculated as counts per milliliter of dialysate per counts per milliliter of dialysand after trichloroacetic acid precipitation. The mean $\mathrm{DFT}_{3}$ is $0.29 \pm 0.02 \%$ (SD) and the mean $\mathrm{DFT}_{4}$ is $0.022 \pm 0.002 \%$ (SD) in normal sera.

\section{RESULTS}

$T_{s}$ and $T_{4}$ concentrations in maternal and cord serum. Mean maternal $\mathrm{T}_{3}$ and $\mathrm{T}_{4}$ concentrations were $161 \mathrm{ng} /$ $100 \mathrm{ml}$ and $12.9 \mu \mathrm{g} / 100 \mathrm{ml}$, slightly above our normal range for both hormones. The mean $T_{3}$ value in cord blood was $51 \mathrm{ng} / 100 \mathrm{ml}$, significantly lower than the mean for the paired maternal values $(P<0.001)$. The individual pairs are depicted in Fig. 1, and the two- to fivefold difference between the maternal and fetal $\mathrm{T}_{3}$ values is apparent. The mean $T_{4}$ in cord serum was 12.6 $\mu \mathrm{g} / 100 \mathrm{ml}$, not significantly different from the maternal level.

In 11 subjects, serum from the umbilical artery and vein were analyzed separately. The mean $\mathrm{T}_{3}$ concentration in the umbilical artery was $42 \pm 3 \mathrm{ng} / 100 \mathrm{ml}$ $(\mathrm{SE})^{3}$ and in the umbilical vein was $43 \pm 4 \mathrm{ng} / 100 \mathrm{ml}$, not significantly different. There was also no statistical difference in the mean $T_{4}$ concentration in these two groups ( $10.1 \pm 0.7$ vs. $10.5 \pm 0.6 \mu \mathrm{g} / 100 \mathrm{ml}$, respectively).

\footnotetext{
${ }^{3}$ All subsequent values given will be mean \pm SEM unless otherwise indicated.
} 
TABLE II

Serum Thyroid Hormone Leiels in Infants During the First 90 Min After Delivery

\begin{tabular}{|c|c|c|c|c|c|c|}
\hline \multirow[b]{3}{*}{ Subject } & \multicolumn{3}{|c|}{$T_{3}$} & \multicolumn{3}{|c|}{$T_{4}$} \\
\hline & \multicolumn{3}{|c|}{ Min after delivery* } & \multicolumn{3}{|c|}{ Min after delivery* } \\
\hline & Cord & 15 & 90 & Cord & 15 & 90 \\
\hline & \multicolumn{3}{|c|}{$\mathrm{ng} / 100 \mathrm{ml}$} & \multicolumn{3}{|c|}{$\mu \mathrm{g} / 100 \mathrm{ml}$} \\
\hline J. B. & 39 & 44 & 166 & 8.3 & 9.9 & 11.1 \\
\hline C. K. $\ddagger$ & 42 & 53 & 180 & 8.2 & 10.0 & 9.8 \\
\hline P. P. & 44 & 78 & 136 & 11.6 & 13.0 & 14.7 \\
\hline T. L. & 46 & 93 & 204 & 11.7 & 一 & 16.6 \\
\hline R. S. & 54 & - & 230 & 9.9 & - & 13.7 \\
\hline S. S. & 65 & 69 & 231 & 12.5 & 12.2 & 18.9 \\
\hline W. B. & 67 & 136 & $390 \S$ & 23.8 & 23.2 & $41.6 \S$ \\
\hline Mean & 51 & 79 & 191 & 12.3 & 13.3 & 14.1 \\
\hline SEM & & 13 & 16 & 2.0 & 2.5 & 1.9 \\
\hline$P \|$ & & $<0.05$ & $<0.001$ & & NS & $<0.00$ \\
\hline
\end{tabular}

* Times are approximate since 3-5 min were usually required to obtain capillary samples.

$\ddagger$ Delivered by elective ceasarian section.

$\S 120 \mathrm{~min}$ sample; not included in calculations.

$\|$ For difference from cord mean ( $t$ test for paired samples).

In addition, there was no statistically significant difference between the total cord $T_{3}$ and $T_{4}$ concentrations in infants following either spontaneous labor or elective cesarian section (for both serum $\mathrm{T}_{3}$ and $\mathrm{T}_{4}, 0.1>P$ $>0.05$ by unpaired $t$ Test).

Free $T_{s}$ and free $T_{4}$ concentrations in maternal and cord sera. The mean dialyzable fraction of $\mathrm{T}_{3}$ was $0.31 \%$ in eight specimens of cord serum, significantly greater than the value of $0.22 \%$ in maternal samples $(P<0.025)$ (Table I). Nevertheless, the mean free $\mathrm{T}_{3}$ concentration in the cord sera was $0.15 \mathrm{ng} / 100 \mathrm{ml}$, less than one-half of the value in the maternal sera ( $P$ $<0.005)$. Despite the slightly higher dialyzable fraction of $\mathrm{T}_{4}$ in cord sera $(0.016 \%$ vs. $0.011 \%)$, the free $\mathrm{T}_{4}$ concentrations were not significantly different in the two groups.

Changes in serum $T_{s}$ and $T_{4}$ concentrations in infants following delivery. As early as $15 \mathrm{~min}$ following delivery, slight but statistically significant increases in $\mathrm{T}_{3}$ concentrations were observed (Table II). The mean $\mathrm{T}_{3}$ concentration in these infants was $79 \mathrm{ng} / 100 \mathrm{ml}$ at $15 \mathrm{~min}$ as opposed to $52 \mathrm{ng} / 100 \mathrm{ml}$ at birth. However, a marked increase in the mean total $\mathrm{T}_{3}$ level to $191 \mathrm{ng} /$ $100 \mathrm{ml}$ was observed at $90 \mathrm{~min}$ after birth, an almost fourfold increase over the mean cord level. In the case of $T_{4}$, the changes observed within this period were less pronounced so that by $15 \mathrm{~min}$ no significant increase was detected. By $90 \mathrm{~min}$, the $\mathrm{T}_{4}$ concentrations were significantly elevated (14.1 vs. $12.3 \mu \mathrm{g} / 100 \mathrm{ml}$ at birth).
TABLE III

Changes in Serum $T_{3}$ and $T_{4}$ During the First 2 Days After Delivery

\begin{tabular}{|c|c|c|c|c|c|c|}
\hline \multirow[b]{2}{*}{ Subject } & \multicolumn{3}{|c|}{$T_{3}$} & \multicolumn{3}{|c|}{$T_{4}$} \\
\hline & Cord & $24 \mathrm{~h}$ & $48 \mathrm{~h}$ & Cord & $24 \mathrm{~h}$ & $48 \mathrm{~h}$ \\
\hline & & \multicolumn{2}{|c|}{$\mathrm{ng} / 100 \mathrm{ml}$} & \multicolumn{2}{|c|}{$\mu \mathrm{g} / 100 \mathrm{ml}$} & \\
\hline C. P. & 45 & 182 & 141 & 12.2 & 25.4 & 19.3 \\
\hline N. N.* & 46 & 182 & 127 & - & - & - \\
\hline E. K. & 69 & 353 & 208 & 15.2 & 21.7 & 23.1 \\
\hline R. S. & 54 & 308 & 287 & 9.9 & 19.9 & 23.4 \\
\hline Mean & 51 & 262 & 191 & 12.4 & 22.3 & 21.9 \\
\hline SEM & 4 & 41 & 37 & 1.5 & 1.6 & 1.3 \\
\hline$P \ddagger$ & & $<0.025$ & $<0.05$ & & $<0.05$ & $<0.05$ \\
\hline$P \S$ & & & NS & & & NS \\
\hline
\end{tabular}

* Delivered by elective cesarian section.

$\ddagger$ For difference from cord value ( $t$ test for paired samples). $\S$ For difference from $24 \mathrm{~h}$ value ( $t$ test for paired samples).

In the four other infants in whom $T_{3}$ concentrations were measured at 24 and $48 \mathrm{~h}$, the levels were significantly elevated over the cord value (Table III). The mean value of $191 \mathrm{ng} / 100 \mathrm{ml}$ at $48 \mathrm{~h}$ did not differ statistically from the value of $262 \mathrm{ng} / 100 \mathrm{ml}$ at $24 \mathrm{~h}$. In the case of $T_{4}$, the 24 -h levels were almost twice those at delivery and were essentially unchanged through the next $24 \mathrm{~h}$.

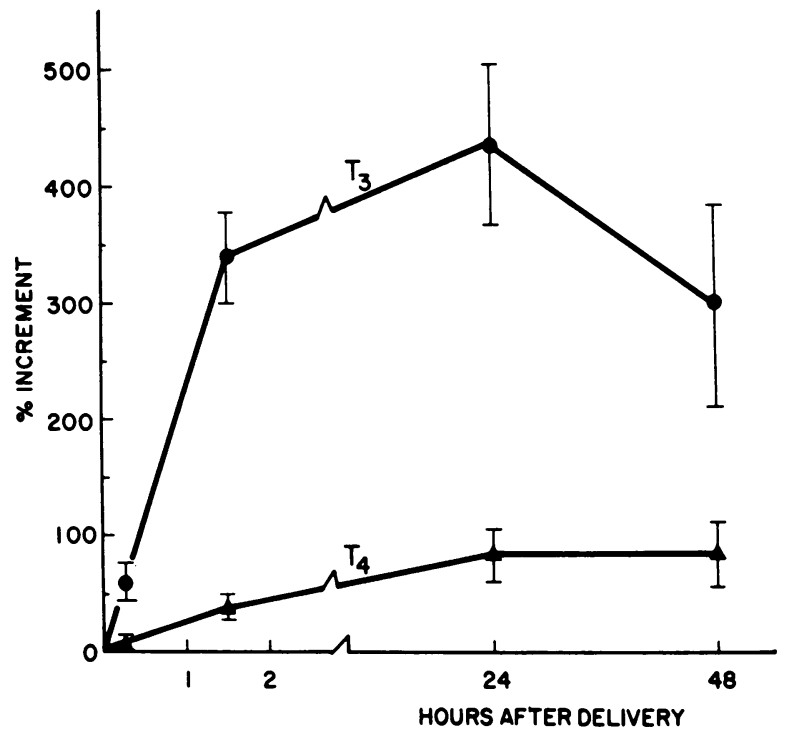

Figcre 2 Total $\mathrm{T}_{3}$ and $\mathrm{T}_{4}$ concentrations in neonatal serum after delivery. Composite representation of the percentage increment in total $\mathrm{T}_{3}$ and $\mathrm{T}_{4}$ observed at the different times studied. Values were calculated as the percentage increase relative to the cord value in each subject. The brackets indicate the SEM. The number of samples is listed in Tahles II and III. 
A composite representation of the relative increments observed at the various times studied shows the differences in the magnitude of the changes for total $T_{3}$ and $\mathrm{T}_{4}$ concentrations (Fig. 2 ). There is a mean increment of $50 \%$ in total $\mathrm{T}_{3}$ content at $15 \mathrm{~min}$, while at $90 \mathrm{~min}$ the $\mathrm{T}_{3}$ concentration is $300-400 \%$ of the cord value. There appears to be no further significant increment at 24 or $48 \mathrm{~h}$. In comparison, the $T_{4}$ concentration increased more slowly and appeared to plateau at $24 \mathrm{~h}$ at a maximum value which was $190 \%$ of the cord level.

\section{DISCUSSION}

The low total $T_{3}$ and high normal $T_{4}$ concentrations found in these cord sera are similar to our previous observations in a smaller group (1). Hotelling and Sherwood, using the Sterling technique for $\mathrm{T}_{3}$ measurement, have also reported that total $T_{3}$ concentration is lower in cord than in maternal sera, though the absolute values reported were higher than those we have obtained (4). The mean $T_{3}$ concentration in cord sera is near the mean we have observed in patients with primary hypothyroidism $(39 \pm 21 \mathrm{ng} / 100 \mathrm{ml}, \mathrm{SD})$ and appears to be the same in both umbilical artery and vein. The dialyzable fractions of $T_{3}$ in maternal and cord sera reported here are in agreement with previous studies by Dussault, Row, Lickrish, and Volpé, though our total $T_{3}$ values are much lower due to technical improvements that have occurred since the earlier studies $(5,6)$. The mean free $T_{3}$ concentration in the cord sera, calculated from the total $\mathrm{T}_{3}$ and dialyzable fraction, is less than one-half of the maternal level as opposed to the free $\mathrm{T}_{4}$ concentration which is not different. The maternal-fetal gradient for free $T_{3}$ indicates there is a placental barrier to the movement of $T_{3}$ from mother to fetus. This finding supports previous evidence suggesting that placental transfer of $\mathrm{T}_{3}$ in the human is incomplete. Earlier reports have shown that in order to cause significant suppression of fetal serum $T_{4}$ concentration, quantities of $\mathrm{T}_{3}$ greatly in excess of physiological requirements (150$300 \mu \mathrm{g} /$ day) must be administered to the mother (5, 7). Along with the previous demonstration of higher levels of TSH in fetal, as opposed to maternal serum, the maternal-fetal free $T_{3}$ gradient is evidence consistent with the hypothesis that the fetal thyroid-pituitary axis functions independently of the mother (8).

The explanation for this phenomenon is not apparent. Current estimates suggest that as much as $40-70 \%$ of the circulating $\mathrm{T}_{3}$ in the adult is derived from peripheral $T_{4}$ to $T_{3}$ conversion $(9,10)$. Therefore, the low $T_{3}$ level in cord sera could be due to a decreased peripheral $T_{4}$ to $T_{3}$ conversion in the fetus. Alternatively, it could be due to a lack of $T_{3}$ secretion by the fetal thyroid due either to decreased $T_{3}$ release or preferential synthesis of $\mathrm{T}_{4}$ in utero. The latter explanation appears to be un- likely in view of the extremely rapid increase in $T_{3}$ concentration observed in the first $90 \mathrm{~min}$ of life. This, in turn, probably results from the increased secretion of TSH which occurs at birth with peak levels found at age $30 \mathrm{~min}$ (2). If so, it would appear to be indicative of adequate thyroidal $T_{3}$ stores. If the rapid increase in $T_{s}$ concentration were to be derived from a rapid increase in $T_{4}$ to $T_{3}$ conversion, the rate of this process would have to be severalfold greater than the rate in adults to account for the abrupt increase in $T_{3}$ concentration. Furthermore, $T_{4}$ to $T_{8}$ conversion would have to decrease just as rapidly to account for the steadily increasing ratio of serum $\mathrm{T}_{4}$ to serum $\mathrm{T}_{8}$ after age $1-2$ $h$, when significant increases in the serum $T$, concentrations begin to appear (Fig. 2). The interpretation of these increases in serum $T_{3}$ and $T_{4}$ concentrations observed after birth as being a result of endogenous TSH secretion is made more attractive by the similarity of the pattern of these changes to the relative increases in serum $T_{3}$ and $T_{4}$ in adults following exogenous $T S H$. In the euthyroid adult, the relative increase in serum $\mathrm{T}_{\mathbf{3}}$ concentration is also greater and earlier than the increase in the serum $T_{4}$ concentration $(1,10)$. While this analysis would appear to be valid in general, final determination of the relative changes in the actual secretion rates of $\mathrm{T}_{3}$ and $\mathrm{T}_{4}$ cannot be made without knowledge of the metabolic clearance rates of both hormones during this period.

It is possible that the low free $T_{3}$ concentration in fetal serum could explain the slight elevation previously observed in fetal serum TSH in the presence of normal free $T_{4}$ levels $(8,11)$. It is also possible that this low free $\mathrm{T}_{s}$ triggers the $\mathrm{TSH}$ release at delivery. However, this interpretation implies an abrupt change in the hypothalamic-pituitary sensitivity to free $T_{3}$ levels from the state which exists prior to delivery. Whether or not such a change occurs is an area for current speculation and further study.

\section{ACKNOWLEDGMENTS}

The authors would like to express their appreciation to Miss Jitka Dockalova, Mrs. Darina Sipula, and Mrs. Fu$\mathrm{Mei} \mathrm{Wu}$ for their careful technical assistance. We are also grateful to Mrs. Loretta Malley for expert secretarial assistance.

These studies were supported by National Institutes of Health Grant no. AM-14283 from the National Institute of Arthritis and Metabolic Diseases and Grant no. 0-20 from the Health Research and Services Foundation of Pittsburgh, $\mathrm{Pa}$.

\section{REFERENCES}

1. Larsen, P. R. 1972. Direct immunoassay of triiodothyronine in human serum. J. Clin. Invest. 51: 1939.

2. Fisher, D. A., and W. D. Odell. 1969. Acute release of thyrotropin in the newborn. J. Clin. Invest. 48: 1670. 
3. Oppenheimer, J. H., R. Squef, M. I. Surks, and H. Haver. 1963. Binding of thyroxine by serum proteins evaluated by equilibrium dialysis and electrophoretic techniques. Alterations in nonthyroidal illness. J. Clin. Invest. 42: 1769.

4. Hotelling, D. R., and L. M. Sherwood. 1971. The effects of pregnancy on circulating triiodothyronine. $J$. Clin. Endocrinol. Metab. 33: 783.

5. Dussault, J., V. V. Row, G. Lickrish, and R. Volpé. 1969. Studies of serum triiodothyronine concentration in maternal and cord blood: transfer of triiodothyronine across the human placenta. J. Clin. Endocrinol. Metab. 29: 595 .

6. Fisher, D. A., and J. H. Dussault. 1971. Contribution of methodological artifacts to the measurement of $\mathrm{T}_{3}$ concentration in serum. J. Clin. Endocrinol. Metab. 32: 675 .
7. Raiti, S., G. B. Holzman, R. L. Scott, and R. M. Blizzard. 1967. Evidence for the placental transfer of triiodothyronine in human beings. N. Engl. J. Med. 277 : 456.

8. Greenherg, A. H., P. Czernichow, R. C. Reba, J. Tyson, and R. M. Blizzard. 1970. Observations on the maturation of thyroid function in early fetal life. J. Clin. Invest. $49: 1790$.

9. Pittman, C. S., J. B. Chambers, Jr., and V. H. Read. 1971. The extra-thyroidal conversion rate of thyroxine to triiodothyronine in normal man. J. Clin. Invest. 50: 1187.

10. Larsen, P. R. 1972. Triiodothyronine: a review of recent studies of physiology and pathophysiology in man. $\mathrm{Me}$ tab. (Clin. Exp.). 21: 1073.

11. Fisher, D. A., C. J. Hosel, R. Garza, and C. A. Pierce. 1970. Thyroid function in the preterm fetus. Pediatrics. 46: 208 . 